\title{
Klambi Lurik Compang-Camping: Sebuah Komposisi Karawitan
}

\author{
SUHARDJONO ${ }^{1}$
}

Jurusan Karawitan, Fakultas Seni Pertunjukan, Institut Seni Indonesia Yogyakarta

\begin{abstract}
Klambi Lurik Compang-Camping Karawitan Composition. This article discusses the creation process of Klambi Lurik Compang Camping karawitan composition. This composition is inspired by Jineman Klambi Lurik, penned by Wasiran -a traditional artist and teaching staff in Karawitan study programme in ISI Yogyakarta. This jineman is favoured by both laypeople and karawitan traditional artists. This composition consists of eight parts, united as one full composition. The creation methods are exploration, improvisation, and shaping.
\end{abstract}

Key words: jineman, klambi lurik, karawitan composition

\section{Pendahuluan}

Sumber inspirasi dari karya seni dalam tulisan ini adalah Jineman Klambi Lurik. Jineman adalah tabuhan gamelan yang fungsinya untuk menjembatani peralihan suasana berat ke suasana yang lebih ringan atau gembira (Soeroso, 1999: 178). Klambi adalah pakaian untuk menutupi anggota badan yang wujud dan namanya bermacam-macam. Lurik adalah motif kain bergaris-garis (Poerwodarminta, 1939: 280). Jineman Klambi Lurik adalah sebuah gending jineman yang bertemakan perasaan cinta dan ketertarikan terhadap penampilan seseorang karena pakaian motif lurik yang dikenakan.

Notasi Jineman Klambi Lurik Laras Slendro Patet Sanga adalah sebagai berikut:

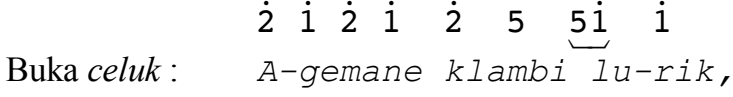

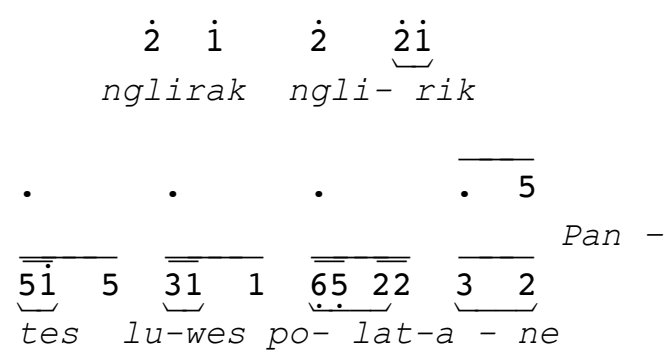

$$
\begin{aligned}
& \overline{.5} \overline{5 \dot{1}} \quad \overline{\overline{66}} \overline{. \dot{2}} \quad \overline{\overline{i 2}} \overline{5 \overline{51}} \overline{\dot{1}} 5 \\
& \text { Dhasare mas kuning nemu giring } \\
& \frac{\text { sri- }}{3 \sqrt{25}} \quad \overline{\overline{35}} 2 \quad \overline{\overline{16} .2} 2 \\
& \text { pat sripit lembeha- ne } \\
& \text {. } \quad . \quad \overline{5 \overline{. \dot{1}}} 6
\end{aligned}
$$

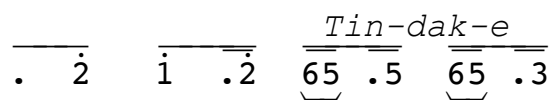

$$
\begin{aligned}
& \text { ka- ya macan lu- we mu } \\
& \overline{5 . \overline{5}} \overline{5} \overline{\overline{.1}} \overline{\overline{65} \overline{.5}} 5 \\
& \text { jud-a- ke pra-wan ndesa } \\
& 2 \overline{6 \dot{1}} \overline{5 \overline{\dot{2} \dot{1}}} \overline{\dot{2}} \overline{\overline{5 \dot{1}}} \dot{i} \\
& \text { sla-ga- ne sarwa prasa-ja }
\end{aligned}
$$$$
\dot{2} \quad i \quad i 6 \underbrace{i .2} \overline{\overline{6 i}}
$$$$
\text { Celuk vocal: Kang da-di kem - bang }
$$$$
\begin{aligned}
& \overline{6 \quad 5} \quad \underbrace{\bar{i} 6}_{\text {bang }}-5 \\
& 5 a
\end{aligned}
$$$$
\text { - } \overline{\overline{5 i}} \overline{6 \quad \overline{2}} \overline{\overline{i 5} \overline{32}} \overline{2 \overline{.2}}
$$$$
\text { Trampil sarta tangguh we- }
$$

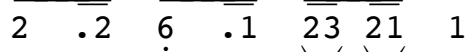$$
\text { wa-ton be- bu-den lu-hur }
$$$$
\begin{array}{lllll}
\hline 5 & \overline{123} & 2
\end{array}
$$

1 Alamat korespondensi: Prodi Karawitan ISI Yogyakarta, Jln. Parangtritis Km. 6,5 Sewon, Yogyakarta, Tlp. 0274-375380, e-mail: suhardjono.kuaetnika@yahoo.com 


\begin{tabular}{|c|c|c|c|c|}
\hline Da & $-t$ & & ke & - guh \\
\hline 1 & 6 & 2 & 65 & 5 \\
\hline ing & & pang & $9-$ & ro-dha \\
\hline 1 & 6 & & .5 & 2 \\
\hline Tan & $S$ & a - & we & - neh \\
\hline 1 & 6 & .5 & $5 \quad 61$ & 1 \\
\hline klam- & $b i$ & & Iu- & rik \\
\hline
\end{tabular}

Karya seni Jineman Klambi Lurik cukup popular di masyarakat Yogyakarta. Beberapa stasiun radio di Yogyakarta yang mempunyai program seni dan budaya selalu memperdengarkan Jineman Klambi Lurik dalam acara kesenian musik tradisi, yaitu uyon-uyon. Salah satu studio yang selalu memutar jineman tersebut adalah Swara Konco Tani. Radio swasta ini mempunyai program uyonuyon enjing mulai pukul 06.00 sampai pukul 08.30 dan uyon-uyon siang. mulai pukul 12.00.

Meskipun karya seni Jineman Klambi Lurik cukup popular di masyarakat, satu hal yang cukup ironis adalah banyak orang tidak tahu seniman yang menciptakan jineman tersebut. Padahal tidak bisa dipungkiri bahwa karya ini cukup digemari oleh masyarakat baik oleh seniman tradisi karawitan maupun masyarakat umum.

Jineman Klambi Lurik diciptakan oleh Wasiran seorang staf pengajar Jurusan Karawitan Fakultas Seni Pertunjukan Institut Seni Indonesia Yogyakarta pada tahun 1993. Karya ini terinspirasi dari pakaian tradisional motiflurik yang dikenakan salah seorang wanita di sebuah hajatan. Dalam acara tersebut Wasiran datang sebagai tamu undangan. Ada sesuatu yang menarik perhatiannya, yaitu pakaian yang dikenakan seorang petugas wanita dalam perhelatan berupa baju dengan motif lurik. Sepulang dari menghadiri acara tersebut, Wasiran termotivasi untuk menggarap karya musik dengan tema baju motif lurik dalam peristiwa yang baru saja dilihatnya di perhelatan. Hasil eksplorasi dan improvisasi yang dilakukan mewujudkan karya seni Jineman Klambi Lurik.

Sejak dimainkan pertama kali, Jineman Klambi Lurik banyak disukai oleh seniman tradisi karawitan di lingkungan komunitas Wasiran di Wonosari Gunungkidul, kemudian merembet dan didengarkan oleh seniman karawitan yang lain.

Pada suatu saat beredar sebuah album kaset rekaman berisi berbagai macam Jineman, salah satunya adalah Jineman Klambi Lurik. Hal ini berdampak pada dua sisi, yaitu positif dan negatif. Hikmah positifnya adalah karya tersebut semakin dikenal luas karena terpublikasi bersamaan dengan beredarnya album kaset rekaman, dari sisi negatif adalah berkaitan dengan hak cipta. Sampai dengan beredarnya album kaset rekaman tersebut, pihak komposer yang menciptakan Klambi Lurik tidak tahu menahu, bahkan juga tidak dicantumkan nama penciptanya.

Berlatar belakang ketertarikan pada fenomena yang menyertai keberadaan Jineman Klambi Lurik, menimbulkan kegelisahan penulis untuk menjadikan karya tersebut menjadi sumber inspirasi untuk menciptakan sebuah karya komposisi karawitan Klambi Lurik Compang-Camping.

Judul "Klambi Lurik Compang-Camping" terdiri dari tiga suku kata. Dua suku kata pertama telah dijelaskan di dalam latar belakang masalah. Kata "compang-camping" adalah sebuah kata ulang untuk menyebut pakaian yang tidak karuan atau buruk (Tim Prima Pena: tanpa tahun: 995) dan identik dengan pakaian yang sudah rusak, banyak yang sobek atau ditambal. Maksud compang-camping dalam judul penciptaan ini diartikan positif. Bila di dalam pakaian istilah compang-camping berkonotasi tidak karuan atau sobek-sobek di beberapa tempat, kaitannya dengan penciptaan ini diartikan sebagai pernakpernik variasi garapan dari Jineman Klambi Lurik yang menjadi obyek sumber penciptaan.

\section{Landasan Penciptaan}

Untuk mewujudkan karya musik Klambi Lurik Compang-Camping dilandasi oleh intuisi/ rasa dan konsep pengolahan secara pikir. Intuisi adalah daya atau kemampuan mengetahui/memahami sesuatu tanpa dipikirkan/dipelajari, bisikan hati, gerak hati (Tim Penyusun, 1988: 580). Pengertian rasa secara umum adalah rangsangan yang mengenai (menyentuh) indera lidah dan kulit (badan). Berkaitan dengan estetika (filsafat keindahan), rasa bersifat universal, rasa yang merupakan pengungkapan makna esensial dari berbagai hal dan dalam pengungkapan itulah terletak keindahan (Soedarso, Sp., 1998: 14).

Dalam hal ini penulis mengeluarkan ide-ide berdasarkan pengalaman rasa selama bergelut di dunia musik baik sebagai pemusik maupun dalam berkarya. Kesimpulan hasil akhir karya/garapan 
menunjukkan bahwa pengalaman rasa lebih mendominasi dibandingkan pengalaman teori yang dimiliki penulis.

Landasan penciptaan yang kedua adalah konsep pengolahan secara pikir. Ada beberapa teknik dalam konsep pengolahan secara pikir:

1.. Augmentasi (augmentation) dalam musik berarti pembesaran nilai, misalnya pada not, interval ataupun akor (Soeharto, 1992: 6). Dalam karawitan adalah pelebaran gatra ( Senen, 2004: 19).

2. Diminusi (diminution) merupakan kebalikan dari augmentasi yang berarti penyempitan gatra. Sebuah teori pengolahan garap kalimat melodi sehingga menjadi lebih kecil dan pendek.

3. Elisi (elision) adalah proses mengolah/menggarap dengan cara menghilangkan atau menghapus salah satu atau dua nada dari suatu motif melodi atau lagu (Atmaja, 2002: 22).

4. Filler berasal dari kata fill bahasa Inggris yang berarti mengisi (Setyo, tanpa tahun: 57) dan penambahan, yaitu terhadap deretan nada, berupa satu gatra maupun satu kalimat lagu.

5. Imitasi (imitation) berarti tiruan/tidak asli (Pena, tanpa tahun: 341). Di dalam konsep penciptaan komposisi karawitan diartikan sebagai peniruan pola tabuhan instrumen tertentu.

6. Pembalikan adalah pertukaran antar nada dalam angkatan (mulai) maupun seleh (akhir).

7. Repetisi (repetition) yang berarti pengulangan atau juga disebut replica (Ensiklopedi Musik, 1992: 157). Teori repetisi digunakan untuk mengulang motif lagu baik melodi instrumen maupun vokal.

\section{Konsep Penyajian}

\section{Ide Garap}

Klambi Lurik Compang-Camping sebagai perwujudan dari hasil eksplorasi terhadap Jineman Klambi Lurik yang diilhami dari rasa ketertarikannya terhadap penampilan seorang wanita yang mengenakan kain motif lurik. Hasil pengamatan Wasiran, wanita tersebut memiliki banyak kesan yang kemudian dituangkan ke dalam syair-syair seperti di bawah ini:
Agemane klambi lurik

Nglirak-nglirik pantes luwes polatane

Dhasare mas... kuning nemu giring

Sripat-sripit lembehane

Tindake kaya macan luwe

Mujudake prawan ndesa

Slagane sarwa prasaja

Kang dadi kembanging bangsa

Trampil sarta tangguh

Wewaton bebuden lubur

Datan keguh ing panggodha

Tan saweneh klambi lurik

Terjemahan:

Pakaiannya baju lurik

Melirik ke sana ke mari

Tatapan matanya sungguh indah

(kulitnya) Kuning langsat

Ayunan tangannya luwes

Jalannya bak macan kelaparan

Menggambarkan gadis pedesaan

Segalanya serba sederhana

Yang menjadi bunga bangsa

Terampil serta tangguh

Juga memiliki budi yang luhur/mulia

Tahan dari segala godaan

Dialah (gadis) berbaju lurik (terjemahan bebas oleh Ratri Probosini)

Tema yang terkandung di dalam jineman tersebut adalah ketertarikan terhadap seorang wanita yang mengenakan pakian bermotif lurik. Melalui pemahaman tema tersebut, penulis melakukan perenungan dan ekplorasi hingga mewujudkan karya seni dengan kandungan suasana sesuai dengan tema yang dimaksud.

Suasana yang terkandung di dalam karya ini adalah rasa cinta bukan secara biologis, tetapi rasa ketertarikan terhadap penampilan seseorang karena pakaian yang dikenakan. Suasana yang dibangun dalam karya ini adalah luapan rasa senang, kagum dan kegembiraan.

\section{Proses Garap}

\section{a. Materi garap}

Musik adalah seni dengan materi pokok yang dihasilkan adalah suara, baik suara vokal manusia maupun suara instrumen/alat musik. Begitu 
juga dalam Klambi Lurik Compang-Camping, materi garap ada pada ricikan dan vokal dengan penonjolan garapannya pada permainan vokal.

\section{b. Sarana garap}

Karya ini dipresentasikan dengan menggunakan instrumen gamelan. Konsep perwujudannya adalah menggunakan instrumen gamelan minimalis, yaitu hanya terdiri dari gender barung, gender penerus dan slentem. Selebihnya adalah garapan vokal.

\section{c. Piranti garap}

Piranti garap yang dimaksud adalah unsurunsur di dalam musik yang menjadi pertimbangan dan acuan untuk mewujudkan karya komposisi. Adapun unsur-unsur tersebut antara lain :

1). Laras

Karya komposisi Klambi Lurik CompangCamping menggunakan tangga nada gamelan laras slendro. Ini sesuai dengan bahan sumber garapan aransemen, yaitu Jineman Klambi Lurik Laras Slendro Patet Sanga.

\section{2). Teknik tabuhan}

Instrumen gamelan yang digunakan adalah kelompok ricikan gender yang teknik memainkannya ditabuh dengan pemukul yang dibalut dengan sejenis kain lunak. Ada tiga teknik menabuh yang diterapkan, yaitu dengan 2 tabuh seperti biasa, dengan 2 tabuh tetapi bagian kain lunak dilepas sehingga menimbulkan suara yang nyaring dan yang ketiga menggunakan satu tabuh. Teknik yang ketiga sering dikatakan mbalung karena seperti teknik menabuh saron (balungan).

\section{3). Irama}

Irama atau wirama adalah unsur musikal terpenting di dalam karawitan. Dalam konteks waktu (laya) aplikasinya lebih relatif, lokal, bahkan kadang-kadang bisa subyektif (Supanggah, 2002:128). Dalam garapan Klambi Lurik Compang-Camping, menggunakan irama cepat dan lambat didasarkan pada pertimbangan dinamika.

\section{4). Dinamika}

Dinamika diterapkan dalam karya ini untuk menghidupkan penyajian. Selain berkaitan dengan permainan irama, dinamik juga dibangun dengan memberi penekanan pada keras-lembut, panjang-pendek, rumit, sederhana dan lain sebagainya. Penekananpenekanan tersebut bukan hanya diterapakan pada permainan instrumen tetapi juga pada permainan vokal.

Untuk lebih mengetahui secara jelas konsep yang diuraikan di atas, berikut ini perwujudan garap Klambi Lurik Compang-Camping terbagi menjadi 8 bagian :

Bagian I sebagai pembuka yang diawali dengan vokal solo putri yang melantunkan tembang macapat Asmarandana. Isi tembang tersebut menceritakan tentang ide gagasan yang kemudian melahirkan karya Jineman Klambi Lurik. Di baris ke dua disusul vokal koor putra dengan iringan instrumen memainkan garap rambangan. Berfungsi sebagai back ground atau ilustrasi untuk lebih menghidupkan suasana selama tembang Asmarandana berlangsung.

Bagian II adalah instrumentalia dan vokal yang dimainkan dengan tempo cepat. Ada teknik imbal antara permainan gender barung dan gender penerus, sedangkan slentem berfungsi melodi dasar. Isi vokal dimaksudkan sebagai pemahaman atas tembang Asmarandana pada bagian I.

Bagian III adalah lagu pokok yang terbagi menjadi beberapa sub bagian. Untuk bagian A berupa satu baris vokal solo putriyang melantunkan baris pertama Jineman Klambi Lurik. Bagian B menggunakan instrumentalia dengan suasa lembut. Bagian $\mathrm{C}$ menggunakan teknik dialog vokal putra dan putri sebagai kombinasi garapan. Bagian D vokal solo putri disertai vokal koor putra unison, sedangkan bagian $\mathrm{E}$ adalah vokal solo putri dengan latar belakang harmoni vokal 3 suara

Bagian IV.A. adalah garap instrumentalia dengan tempo cepat. Ricikan slentem hanya memainkan satu nada berfungsi sebagai ketukan, sedangkan gender barung dan penerus memainkan melodi vokal setengah bagian awal dengan teknik mbalung. Bagian IV.B. memainkan setengan bagian akhir dengan garap jineman seperti garap tradisi dalam karawitan.

Bagian $\mathrm{V}$ adalah pengulangan bagian III.B. Bagian VI adalah pengulangan dari bagian III.C. sampai III.E, tetapi pada penggarapan harmoni 3 suara ada sedikit perubahan untuk suara vokal II dan III. 
Bagian VII.A. adalah pengulangan bagian IV.A. dengan penambahan suara tepuk tangan dan teriakan vokal. Bagian VII.B. merupakan pengulangan IV.B. tetapi berbeda pada teknik vokal. Pada bagian VII.B. penyajian vokal menggunakan teknik dialog antara vokal putra dan putri.

Bagian VIII adalah bagian akhir dari Klambi Lurik Compang-Camping. Semua unsur vokal dan instrumen ditampilkan dengan irama cepat. Bagian akhir ini diharapkan mampu mencapai klimak sebagai penutup seluruh rangkaian komposisi karawitan yang disajikan.

\section{Metode/Proses Penciptaan}

Untuk mewujudkan karya ini, mengacu metodologi rumusan Alma M. Hawkins yang dikutip I Made Bandem yaitu: eksploration (eksplorasi), improvisation (improvisasi) dan forming atau pembentukan (Bandem, 2001:6).

\section{Eksplorasi}

Eksplorasi adalah salah satu metode dalam proses menciptakan sebuah karya seni diartikan sebagai penjelajahan atau penjajakan terhadap obyek tertentu dengan tujuan untuk memperoleh pengetahuan yang lebih banyak. Kegiatan yang termasuk dalam eksplorasi adalah berpikir, berimajinasi, merasakan dan merespon (Hawkins, 1990: 27). Dalam hal ini penulis melakukan eksplorasi untuk menemukan obyek sebagai bahan penciptaan yang akan dilakukan.

Media instrumen yang digunakan dalam penciptaan ini adalah gamelan Jawa. Pemilihan ini didasarkan pada pertimbangan bahwa bidang seni ini sudah lama digeluti, sehingga eksplorasi yang dilakukan mengarah pada nuansa Jawa.

Ada beberapa tahapan yang dilakukan penulis dalam kegiatan eksplorasi, yaitu:

a. Mencari data dan mengumpulkan sumbersumber yang berkaitan dengan berbagai macam lagu, gending, langgam, dolanan, jineman dan tembang. Selain itu penulis mendengarkan program-program yang disiarkan melalui radio terutama yang berkaitan dengan seni budaya Jawa.

b. Dari hasil kegiatan eksplorasi yang dilakukan tersebut di atas, penulis tertarik dengan Jineman Klambi Lurik yang disiarkan Radio Kanca Tani melalui program Uyon-Uyon Enjang setiap pagi mulai pukul 06.00 WIB sampai pukul 08.30 WIB. Dari rasa ketertarikan tersebut kemudian menentukan pilihan pada Jineman Klambi Lurik sebagai bahan sumber penciptaan.

c. Mencari sumber asli Jineman Klambi Lurik dengan menemui penciptanya, yaitu Wasiran.

d. Mengapresiasi berbagai aransemen gending, lagu, langgam, dolanan, jineman maupun tembang dari berbagai variasi garap. Hal ini dilakukan untuk mencari tafsir lain yang kemungkinan belum banyak dilakukan oleh komposer terdahulu.

e. Membuka kembali referensi penulis yang diperoleh dari pengalaman-pengalaman berkesenian dan berinteraksi selama ini dengan berbagai komunitas seni.

\section{Improvisasi}

Tahapan yang dilakukan setelah eksplorasi adalah improvisasi. Pada dasarnya improvisasi memberikan kesempatan yang lebih besar bagi imajinasi, seleksi dan mencipta (Hawkins, 1990: 27). Ada pendapat bahwa improvisasi itu bersifat spontan, kreatif sementara, tidak tetap (baku) dan tidak berbentuk selesai (Smith, 1985: 31). Mengacu pada beberapa pendapat tersebut, dilakukan teknik-teknik proses penggarapan atas materi bahan Jineman Klambi Lurik.

Referensi pengalaman selama berproses musik baik di dalam sebuah komunitas seni, sanggar maupun dengan teman-teman seniman musik, mendorong penulis untuk menjadikan bahan aransemen yang akan dilakukan. Hal ini sesuai dengan pendapat Alma M. Hawkins bahwa dalam proses improvisasi penyediaan dorongan motivasi, menyebabkan dirinya merespons dan membuat tindakan yang lebih dalam (inner), akhirnya menghasilkan respons unik seseorang (Hawkins, 1990: 33).

Selain membuka referensi pengalaman, penulis juga menerapkan beberapa konsep penciptaan dalam karawitan yang ditulis oleh I Wayan Senen. Dikatakan bahwa ada beberapa teknik yang biasa digunakan dalam proses pengolahan elemen tersebut antara lain pengulangan (repetition), pelebaran gatra (augmentation), penyempitan gatra (diminution), perpindahan patet (modulation), peniruan pola tabuhan instrumen tertentu (imitation), pemindahan pola ritmis dengan nada 
tertentu ke nada lain (sequence), pembalikan (inversion), penambahan/isian(filler), pengurangan (elision), perombakan (retrogression), pemindahan berat-ringan (ding-dong) nada, pemindahan pola ritme ke elemen melodi, pemindahan pola tempo dan lain sebagainya (Senen, 2004:19).

Di antara beberapa teknik tersebut, yang digunakan dalam mewujudkan Klambi Lurik Compang-Camping adalah :

a. Pengulangan

Di dalam karya ini ada beberapa teknik pengulangan yang dilakukan meliputi pengulangan nada dan pengulangan melodi. Baik instrumen slentem, gender barung maupun gender penerus menggunakan teknik pengulangan.

1). Pengulangan instrumen masing-masing memainkan melodi yang berbeda tetapi bertumpu pada nada yang sama, seperti di bawah ini:

\begin{tabular}{|c|c|c|c|c|c|c|c|c|}
\hline Slt. & : & - & 2 & . & 5 & - & 6 & • \\
\hline \multirow[t]{3}{*}{ Gdr. } & : & .6 & 5 & 35 & .2 & .2 & 5 & 6 \\
\hline & & - & 2 & - & 5 & . & 6 & • \\
\hline & & .6 & 5 & 35 & .2 & .2 & 5 & 6 \\
\hline Slt. & : &. & 2 &. & 5 & . & 6 & . \\
\hline \multirow[t]{3}{*}{ Gdr. } & : & .6 & 5 & $\overline{35}$ & .2 & .2 & 5 & 6 \\
\hline & & - & 5 & - & $\underline{6}$ & . & $i$ & : \\
\hline & & .6 & 5 & $\overline{35}$ & .2 & .5 & 6 & $i$ \\
\hline Slt. & : & . & 5 &. & 6 & . & 1 & . \\
\hline \multirow[t]{3}{*}{ Gdr. } & : &.$\dot{1}$ & 6 & 56 &.$\dot{1}$ & .5 & 6 & i \\
\hline & & - & 5 & $\dot{-}$ & 6 & . & 1 & • \\
\hline & &.$\dot{1}$ & 6 & 56 &.$\dot{1}$ & .5 & 6 & i \\
\hline Slt. & : & . & 5 & . & 6 & - & 1 & • \\
\hline \multirow[t]{3}{*}{ Gdr. } & : & $\bar{i}$ & 6 & $\overline{56}$ &.$\dot{1}$ & .5 & 6 & $i$ \\
\hline & & . & i & . & 5 & . & 6 & . \\
\hline & & . & i & . & 5 & . & 6 & \\
\hline
\end{tabular}

2). Teknik repetisi diterapkan untuk pengulangan melodi dan syair pada

penyajian vocal seperti di bawah ini :

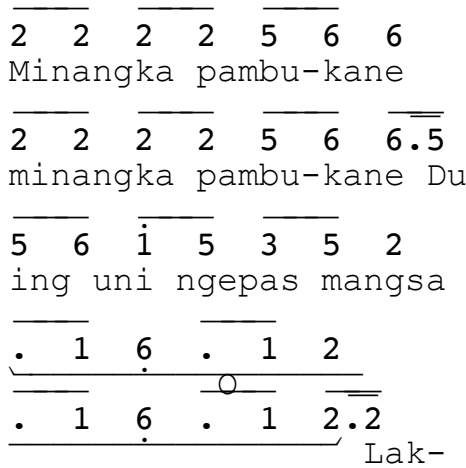

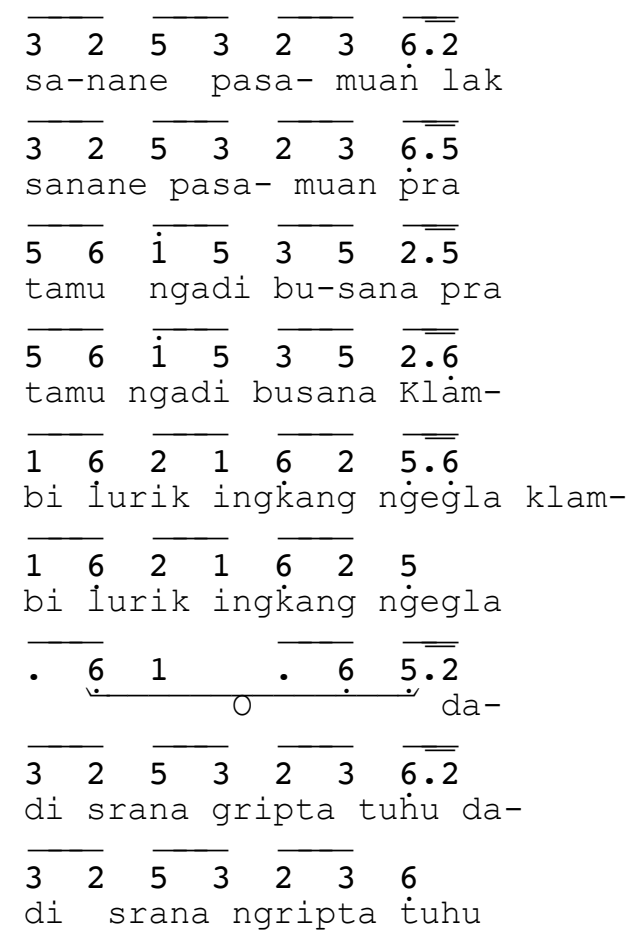

b. Imitasi atau Peniruan

1). Teknik imitasi diterapkan pada instrumen dan vokal. Misalnya pola permainan gender barung dan gender penerus menirukan teknik imbal instrumen saron ricik.

Gdr. Br. : . 2 • 5 • 2 . 5 . 2 . 5

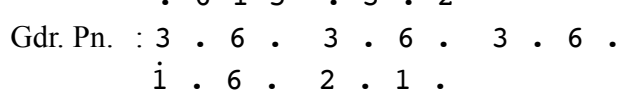

2). Teknik tabuhan gender barung dan gender penerus menirukan teknik tabuhan instrumen saron, yaitu dengan satu tabuh/pemukul. Selain itu juga menirukan pola melodi vokal baik ritme maupun nadanya. 
Gender barung dan penerus:

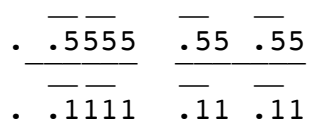

Ritme dan nada yang dimainkan menirukan vokal seperti di bawah ini:

$$
\begin{array}{lll}
\cdot 1 & \overline{1} 1 & 1
\end{array}
$$

Vokal I :

$$
\begin{aligned}
& \begin{array}{lll}
\text { A-gema-ne } & & \\
\text {. }^{1} & 1 & 1
\end{array} \\
& \text { klambi lurik } \\
& \text {. } 5 \overline{55} 5
\end{aligned}
$$

Vokal II :

$$
\begin{array}{rrr}
\frac{\text { A-ge-mane }}{5} & \frac{5}{5} \\
\text { klambi } & \text { lurik } \\
\text {. } & \quad \bar{i} \bar{i} i
\end{array}
$$

Vokal III :

$$
\begin{array}{ll}
\frac{1}{1} i & \frac{\text { A-ge-mane }}{\cdot i} i \\
\text { klambi lurik }
\end{array}
$$

Vokal solo putri pada bagian I melantunkan Tembang Asmarandana. Jenis tembang tersebut sudah ada dalam deretan tembang macapat. Pemilihan Asmarandana didasarkan pada sifat parasaja dan sengsem (Sunardi, 2004:2).

\section{c. Teknik isian}

Penerapan teknik isian dalam karya komposisi ini ada pada garap instrumen dan garap vokal. Misalnya instrumen gender barung dan gender penerus mengisi tabuhan instrumen slentem dengan teknik imbal saron. Instrumen gender barung dan gender penerus mengisi tabuhan instrumen slentem dengan teknik unisono, yaitu secara bersama-sama baik melodi maupun tabuhannya.

Selain isian dengan instrument dan vokal, ada bagian permainan melodi instrumen slentem dan gender dibarengi dengan isian suara tepuk tangan yang dilakukan oleh semua vokalis.

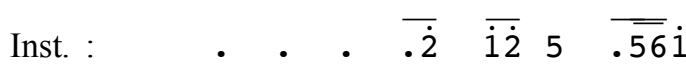

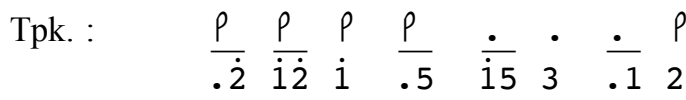

$$
\begin{aligned}
& \begin{array}{llllllll}
.2 & 12 & 1 & .5 & 15 & 3 & .1 & 2 \\
. & p & \rho & . & p & . & p
\end{array}
\end{aligned}
$$

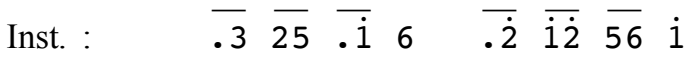

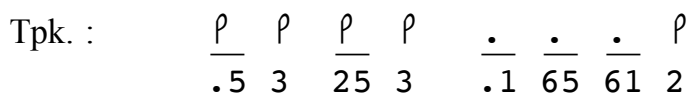

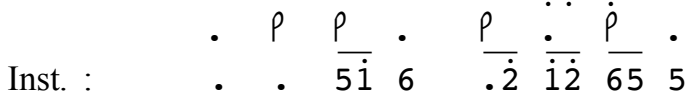

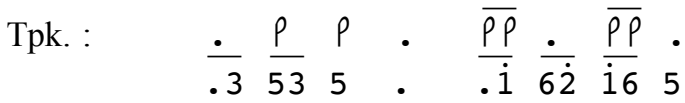

$$
\begin{aligned}
& \text {. } p \rho . \frac{.1}{\rho p} \cdot \frac{16}{\rho p} \text {. } \\
& \text { Inst. : } \quad \begin{array}{llllll}
\hline \dot{1} & 5 & \overline{2} \dot{i} & \dot{z}
\end{array} \\
& \text { Tpk. : } \quad P \quad P \text {. } P \quad P
\end{aligned}
$$

d. Teknik harmoni

Garapan karya musik Klambi Lurik CompangCamping menggunakan instrumen minimalis dan didominasi oleh garapan vokal. Garapan harmoni suara vokal yang terbagi menjadi 3 suara sangat menonjol dalam garapan, seperti vokal di bawah ini:

1). Pembagian suara I - vokal putra (Pa I), suara II - vokal putra (Pa II) dan suara III - putri (Pi).

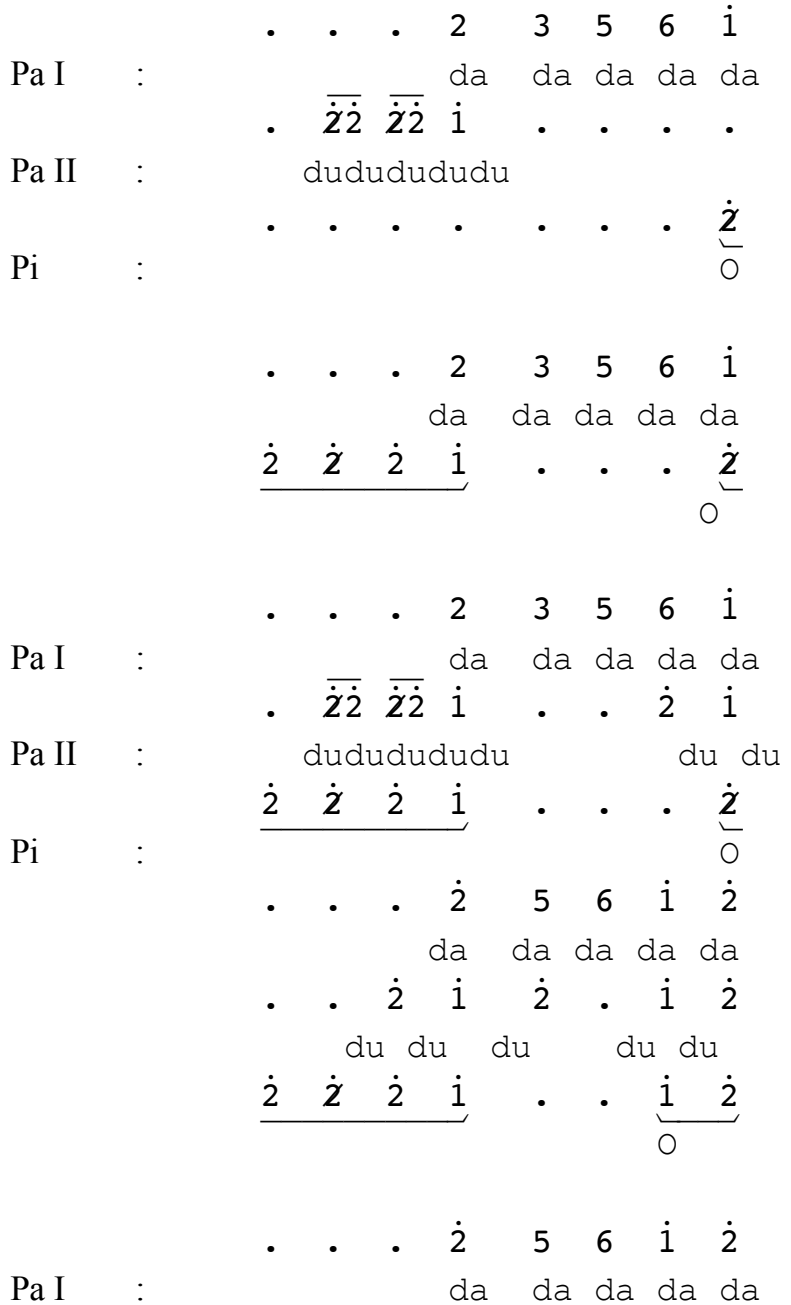


- $\overline{\dot{2} \dot{i}} \overline{6 \dot{1}} \dot{2} \quad . \quad \overline{\dot{2} \dot{1}} \overline{6 \dot{1}} \dot{2}$

Pa II

Pi

$$
\begin{aligned}
& \text { - } \begin{array}{lllllll} 
& 1 & 6 & 5 & 6 & &
\end{array} \\
& \text { da da da da da da }
\end{aligned}
$$

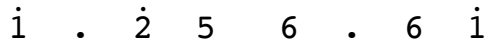

$$
\begin{aligned}
& \text { du du du du du du } \\
& \text { - } i \text {. } 5 \text {. } 6 \text {. } i
\end{aligned}
$$

2). Pembagian vokal I - suara putra (Pa I), vokal II - suara putra (Pa II) dan vokal III - suara putri (Pi).

$$
\overline{\overline{5 i}} \overline{6 \overline{. \dot{2}}} \overline{\overline{15} \overline{32}} \overline{2 \overline{.2}}
$$

Vokal I : Trampil sarta tangguh we-

Vokal II : $\quad$ Trampil tatag tangguh we-

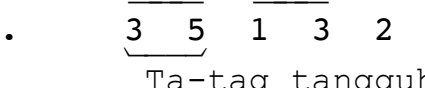

Vokal III : $\quad$ Ta-tag tangguh

$$
\overline{2.2} \overline{6 . \overline{1.1}} \overline{\overline{23} \overline{21}} 1
$$$$
\text { waton bebu-den luhur }
$$$$
\overline{\dot{6} .6} \overline{6 \overline{6.5}} \overline{\overline{6 \dot{1}} \overline{65}} 5
$$$$
\text { waton bebu-den luhur }
$$$$
\overline{.3} \overline{26} \overline{5 \overline{61}} 1
$$$$
\text { be- bu-den lu-hur }
$$

$\overline{5} \overline{1 \quad 2} \quad \overline{\overline{23}} 2 \quad 2$

Vokal I : $\quad$ Da-tan ke-guh

$$
\text { - } 6 \overline{56} \overline{\overline{6 i}} 6
$$

Vokal II : $\quad$ Da-tan ke- guh

$$
\text { - } 1 \longdiv { 2 3 } \overline { 5 6 } 5
$$$$
\text { Vokal III : } \quad \text { Da }-\tan \text { keguh }
$$

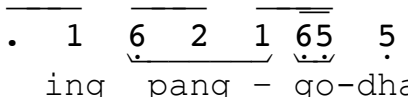

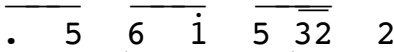

$$
\begin{aligned}
& \text { ing pang- go-dha } \\
& \begin{array}{llllll}
2 & 2 & 1 & 6 & 51 & 6
\end{array} \\
& \text { ing pang - godha }
\end{aligned}
$$

$$
\begin{aligned}
& \text { - } 16 \quad \overline{3.5} 2 \\
& \text { Vokal I : } \quad \text { Tan sa - we- neh } \\
& \text { Vokal II : } \quad \text { Tan sa - we- neh } \\
& \text { Vokal III : } \quad \text { Tan sa - } \underbrace{5}_{\text {we- neh }} \\
& \overline{\text { - } 1} \underset{\mathrm{klam}-\mathrm{bi}}{\overline{6.5}} \underbrace{\overline{5 \cdot \overline{61}}}_{\mathrm{lu}-\mathrm{rik}} 1 \\
& \overline{5} \underbrace{\overline{3.2}}_{\text {klam-bi }} \underbrace{\overline{255}}_{\text {lu- rik }} 5
\end{aligned}
$$

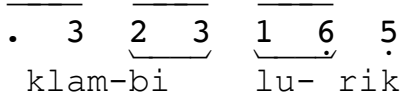

3). Pembagian vokal I - suara putra (Pa I), vokal II - suara putra (Pa II) dan vokal III - suara putri (Pi).

$$
\text { - } \overline{5 \dot{1}} \overline{6 \overline{. \dot{2}}} \overline{\overline{15} \overline{32}} \overline{2 \overline{.2}}
$$

Vokal I : Trampil sarta tangguh we -

Vokal II :

$$
\begin{aligned}
& \text { - } \underbrace{\overline{2} i \overline{5} \quad \overline{1} 6}_{0} \\
& \begin{array}{lllll}
\overline{3} \quad 5 & \overline{1} & 3 & 2
\end{array}
\end{aligned}
$$

Vokal III :

$\overline{2.2} \overline{6 \overline{6.1}} \overline{\overline{23}} \overline{21} 1$ waton bebu-den luhur

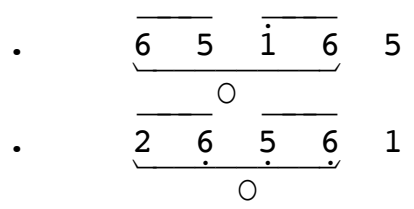

Vokal I :

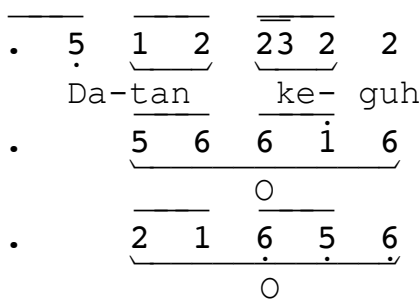

Vokal III :

$$
\begin{aligned}
& \text { - } 11 \underbrace{\overline{6 \quad 2} \overline{1}}_{\text {ing }} \stackrel{\overline{65}}{5} \\
& \text { - } \underbrace{\overline{6} \quad \overline{5} 3}_{0} \\
& \begin{array}{llll}
\overline{2} 3 & 5 & 6
\end{array}
\end{aligned}
$$




\begin{tabular}{|c|c|c|c|c|}
\hline & - 1 & 6 & 3.5 & 2 \\
\hline Vokal I : & $\operatorname{Tan}$ & $\mathrm{sa}-$ & we- & neh \\
\hline & - & 23 & $5 i$ & 6 \\
\hline Vokal II : & & 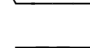 & 0 & \\
\hline & . & $6 i$ & $\overline{53}$ & 2 \\
\hline Vokal III : & & & 0 & \\
\hline & . 1 & $\overline{6.5}$ & $\overline{5 \overline{61}}$ & 1 \\
\hline & $\mathrm{kl}$ ar & $n-b i$ & $1 \cdot \overline{l u-}$ & rik \\
\hline & .5 & 3 & $\overline{2 \overline{35}}$ & 5 \\
\hline & & 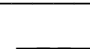 & O & \\
\hline & . 3 & 2 & $\overline{1 \overline{65}}$ & 5 \\
\hline
\end{tabular}

e. Teknik dialog

Teknik dialog pada karya ini diadopsi dari teknik dialog yang biasanya banyak digunakan pada seni peran, seni pedalangan dan seni tari. Teknik tersebut diwujudkan dalam karya Klambi Lurik Compang-Camping sebagai berikut :

1). Dialog vokal putra (Pa) dengan vokal putri (Pi) dengan karakter yang berbeda

\begin{tabular}{|c|c|c|}
\hline Biasa & $\begin{array}{l}\dot{2} \quad \mathrm{i} \\
\frac{\mathrm{nglirak}}{\mathrm{Pi}}\end{array}$ & $\frac{\dot{\mathrm{ngli}} \underbrace{2 i k}_{\mathrm{Pa}}}{\mathrm{Pa}^{2}}$ \\
\hline Galak & $\begin{array}{l}\dot{2} \quad \mathrm{i} \\
\frac{\mathrm{nglirak}}{\mathrm{Pi}}\end{array}$ & $\begin{array}{l}\dot{2} \quad \begin{array}{l}\mathrm{i} \\
\mathrm{ngli}-\mathrm{rik}\end{array} \\
\mathrm{Pa}\end{array}$ \\
\hline Nggalur & $\frac{\underbrace{}_{\mathrm{Ngli}} \underbrace{\dot{2 . i}}_{-\mathrm{rak}}}{\mathrm{Pi}}$ & 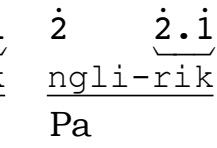 \\
\hline
\end{tabular}

2). Dialog antara vokal dengan instrumen gamelan yang terdiri dari demung, saron ricik, saron peking, gender barung dan gender penerus. Suara vokal dibawakan dengan tempo lambat. Berlawanan dengan instrumen yang dibawakan dengan tempo cepat.

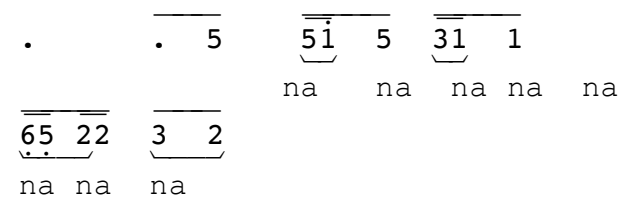

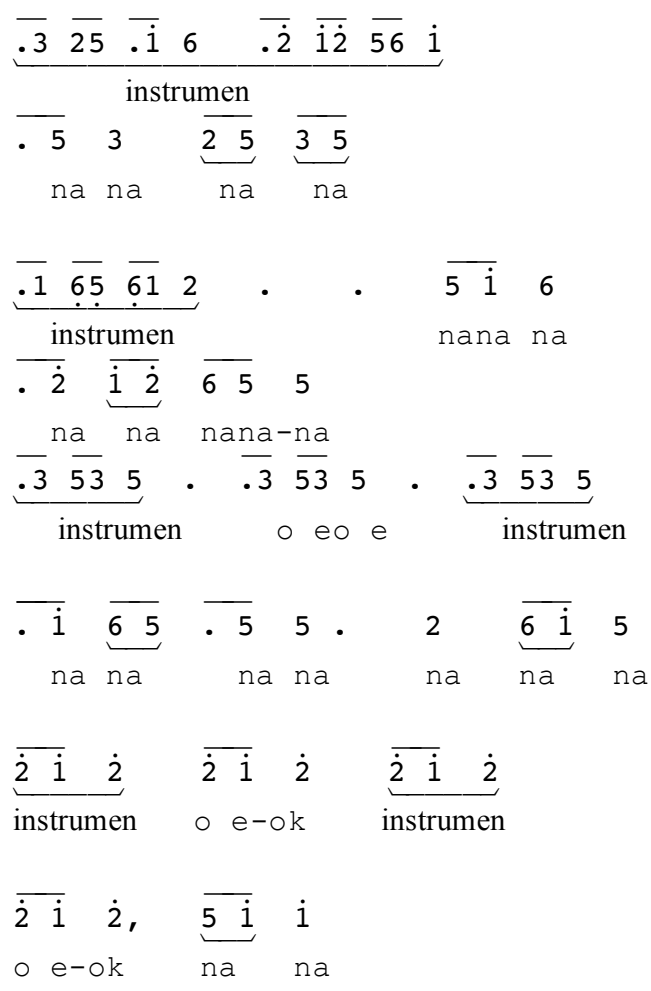

\section{Pembentukan}

Akumulasi dari hasil eksplorasi, improvisasi dan referensi pengalaman berinteraksi di dunia seni khususnya seni karawitan dan musik tersebut disusun dalam sebuah konsep garapan dengan tafsir komposisi. Dimulai dengan mencoba membuat kerangka garapan kemudian dilanjutkan penggarapan dengan tafsir komposisi karawitan sampai menemukan bentuk perancangan aransemen sesuai dengan ide-ide yang dimaksud. Melalui metode ini hasil dari penciptaan sudah dapat diketahui. Pada dasarnya pembentukan merupakan kebutuhan membuat komposisi yang tumbuh dari hasrat manusia untuk memberi bentuk terhadap sesuatu yang ia temukan (Hawkins, 1990: 33).

Penciptaan ini banyak mengadopsi ilmuilmu yang diwujudkan dalam notasi Kepatihan yang sudah lazim digunakan di dalam karawitan. Untuk selanjutnya notasi ini sebagai pijakan untuk memasuki proses studio dengan melakukan latihan.

\section{Penutup}

Karya seni Klambi Lurik Compang-Camping terlahir dari Jineman Klambi Lurik yang diciptakan oleh Wasiran pada tahun 1993. Jineman tersebut terinspirasi ketertarikan terhadap penampilan 
seseorang yang mengenakan pakaian dengan motif lurik, sehingga segala tingkah lakunya juga menjadi perhatian dan tidak luput dari pengamatannya.

Konsep utama dalam penciptaan ini adalah ide dan proses garap meliputi materi, sarana dan piranti yang didalamnya terkandung adanya laras, teknik, irama dan dinamik. Dengan menerapkan beberapa konsep tersebut mewujudkan garapan yang terbagi menjadi 8 bagian sebagai kesatuan yang utuh sebuah karya komposisi karawitan dengan metodologi berupa eksplorasi, improvisasi, dan pembentukan.

Harapan penulis bahwa karya ini sebagai embrio dan memotivasi munculnya karya-karya yang lain. Selain juga ikut berpartisipasi melestarikan dan mengembangkan seni tradisi khususnya karawitan.

\section{Kepustakaan}

Hastanto, Sri. "Karawitan: Serba-Serbi Karya Ciptaannya", dalam SENI, Jurnal Pengetahuan dan Penciptaan Seni, I/01 Mei 1991, BP ISI Yogyakarta.

Hawkins, M. Alma. 1990. Terj. Y. Sumandiyo Hadi. Mencipta Lewat Tari. Yogyakarta: Institut Seni Indonesia Yogyakarta.

Martopangrawit. 1975. Pengetahuan Karawitan I. Surakarta: ASKI, Surakarta.
Senen, I Wayan. 2004. "Konsep Penciptaan dalam Karawitan”. Makalah Lokakarya Metodologi Penelitian Jurusan Karawitan FSP ISI, Yogyakarta.

Smith, Jacqueline. 1985. Komposisi Tari Sebuah Petunjuk Praktis Bagi Guru. Terj. Ben Suharto. Yogyakarta: Ekalisti.

Soeroso. 1999. Kamus Istilah Karawitan Jawa. Yogyakarta: Institut Seni Yogyakarta.

Sunardi. 2004. "Angrakit Endah Edining Gesang Bebrayan Lumantar Macapat". Diktat Macapat. Yogyakarta: Sekolah Menengah Karawitan Indonesia Yogyakarta.

Poerwadarminta, et. al. 1939. Baoesastra Djawa. Jakarta: J.B. Wolter Uitgever Maatschipij.

Poerwadarminta, W.J.S. 1985. Kamus Umum Bahasa Indonesia. Jakarta: PN Balai Pustaka.

Supanggah, Rahayu. 2002. Bothekan Karawitan I. Jakarta: Ford Fondation dan Masyarakat Seni Pertunjukan Indonesia.

Tim Prima Pena. tanpa tahun. Kamus Besar Bahasa Indonesia. Tanpa kota: Gita Media Press.

\section{Informan:}

Wasiran. 61 tahun. Pencipta Jineman Klambi Lurik, Dosen Jurusan Karawitan Fakultas Seni Pertunjukan ISI Yogyakarta.

Ratri Probosini. 47 tahun. Dosen Mata Kuliah Bahasa Daerah Jurusan Karawitan Fakultas Seni Pertunjukan ISI Yogyakarta. 